\title{
A História das duas Índias e os colonizadores da América
}

\author{
The History of the two Indies and the colonizers of America
}

Luiz Francisco Albuquerque de Miranda*

\begin{abstract}
Resumo
O artigo analisa como a "histórica filosófica" do século XVIII representou os colonos ibéricos que chegaram à América a partir do século XVI. Busca-se identificar o caráter que lhes foi atribuído e como a historiografia ilustrada avaliou as suas atuações no Novo Mundo. A Ilustração concebeu uma "história universal" da qual a expansão ibérica fazia parte e, partindo do pressuposto de que o progresso do "espírito humano" estava em curso, pensou e julgou a colonização promovida pelos impérios português e espanhol. O resultado dessa reflexão é o objeto deste texto. Confere-se especial atenção à Histoire des deux Indes do Abade Raynal, uma das principais obras ilustradas a respeito da expansão ultramarina.
\end{abstract}

Palavras-chave: História Filosófica; Colonização da América; Progresso; Raynal.

\begin{abstract}
The article analyses how the "philosophical history" of the XVIII century represented the Iberian colonists who arrived in America from the XVI century onwards. It aims to identify the character which was attributed to them, as well as how the illustrated historiography evaluated their role in the New World. The Enlightenment conceived a "universal history" in which the Iberian expansion took part and, from the assumption that the progress of the "human spirit" was under way, considered and judged the colonization promoted by the Portuguese and Spanish empires. The result of this reflection is the object of this text. Special attention is given to Historie des deux Indes by Raynal, the abbot, one of the main illustrated works regarding the overseas expansion.
\end{abstract}

Keywords: Philosophical History; Colonization of America; Progress; Raynal.

\section{Introdução: a América e a "história filosófica"}

A Ilustração renovou a historiografia ao conceber uma história da civilização que sintetizava os progressos do "espírito humano". No século XVIII, emergiu uma ideia de história da "humanidade" que, organizando inúmeras informações a respeito de diferentes experiências sociais, esboçou uma visão de conjunto daqueles progressos. Como lembra Pagden (2002, p. 186-189), no período das Luzes, antes das concepções racistas dos séculos XIX e XX, o verbo "civilizar" pressupunha "uma natureza humana

\footnotetext{
* Doutor em Filosofia pela Universidade Estadual de Campinas (UNICAMP). Professor da Universidade Federal de São João Del Rei (UFSJ).
} 
universal e uma lei universal da evolução humana" (do nomadismo ao sedentarismo urbano, da caça à agricultura e comércio, etc.). As diferenças entre os povos seriam explicadas por fatores climáticos, tipos de governo, migrações, etc, mas não impediriam a possibilidade de desenvolvimento civilizatório de todos os povos. Venturi (2003, p. 25-28) pensa que essa "teoria do progresso" concebeu um "caminho infinito" para a perfectibilidade humana, um percurso global inteligível a partir do conhecimento histórico.

É verdade que parte da produção historiográfica do século XVIII ainda procurava identificar modelos de comportamento humano que, supostamente, se repetiam ao longo do tempo. Ao conhecê-los, o historiador adquiriria um repertório das melhores respostas aos problemas sociais já experimentados no passado. Nessa concepção cíclica da história, como sugere Koselleck (2012, p. 16-17), o tempo não é compreendido como processo de eventos inéditos. Notamos ecos dessa concepção, que predominou até o início do século XVIII, mesmo em Voltaire, um dos inovadores da historiografia. Quando definiu a "utilidade da história" no verbete "História" escrito para as Questões sobre a Enciclopédia (primeira publicação em 1775), o filósofo afirmou que ela deveria ser "exemplar" e mostrar os "erros" do passado, tornando-os familiares e prevenindo para que não se repetissem (VOLTAIRE, 1879, v. 19, p. 357358).

Todavia, os filósofos das Luzes tenderam a superar essa perspectiva. Koselleck (2012, p. 316-320) nota que a concepção de história mudou quando o conceito de progresso deu forma a um "novo horizonte de expectativa". Então, "o objetivo de uma perfeição possível, que antes só podia ser alcançado no além, foi posto a serviço de um melhoramento da existência terrena", ou seja, "o objetivo da perfeição foi temporalizado". No século XVIII, a história começou a ser entendida como "processo de contínuo e crescente aperfeiçoamento" e "o horizonte de expectativa passa a incluir um coeficiente de mudança que se desenvolve com o tempo". O "espaço de experiência" também se alterou: o conceito de progresso único e universal lhe conferia um "coeficiente de variação temporal". A novidade era que "as expectativas para o futuro se desvincularam de tudo quanto as antigas experiências haviam sido capazes de oferecer", separando os limites entre "espaço de experiência" e "horizonte de expectativas". O futuro seria diferente e melhor, não repetiria o passado. A "história foi vista e experimentada como única" em seu todo, ou seja, "como totalidade aberta para 
um futuro portador de progresso" e, desdobrando-se como unicidade contínua, "não podia ser ensinada como exemplo".

Aos poucos, a historiografia das Luzes deixava de procurar casos exemplares e de oferecer ao presente as "lições" do passado. Apesar das oscilações, o movimento global do aperfeiçoamento humano mobilizou cada vez mais a produção historiográfica do século XVIII. Em vez de guardar um ensinamento sempre válido, a história dos ilustrados buscava, cada vez mais, apreender o passado como dinâmica transformadora capaz de melhorar as instituições e o comportamento dos homens. Acreditava-se que, por diversos meios, os homens deixavam para trás o passado e entravam em um "futuro aberto", portador de "diferentes possibilidades", sendo o presente uma "transição" no qual o sujeito histórico deveria fazer suas escolhas e agir (GUMBRECHT in ARAÚJO, MOLLO, NICOLAZZI, 2011, p. 28-37).

No mesmo texto em que afirmava o papel da história na demonstração dos “erros" do passado, Voltaire (1879, v. 19, p. 334) também anunciava outra função para o conhecimento histórico: ensinar nossos "deveres e direitos". Referia-se aos deveres e direitos dos cidadãos de Estados bem estabelecidos. Sendo bom cidadão, o indivíduo contribuía para o avanço da vida civilizada e para o progresso do gênero humano. Assim, o filósofo relacionou vida civil e aperfeiçoamento da espécie. Mas se não havia exemplos imitáveis, como apreender o sentido histórico da vida civil? Não se limitando ao relato de batalhas e aventuras dos príncipes, mas instruindo a respeito das leis e dos costumes dos povos, assim como de seu comércio e de sua agricultura. O historiador deveria analisar as principais leis e instituições (os "corpos") das nações e esclarecer suas mudanças ao longo do tempo (VOLTAIRE, 1879, v. 19, p. 365-366), apresentando-as de modo a descrever um processo unificado. Para ensinar os direitos e deveres dos homens e ajudar a torná-los cidadãos responsáveis, era necessário mostrar como os povos ordenaram sua vida em comum, comparando as diversas experiências sociais e seus desdobramentos. O objetivo era compreender como essa multiplicidade, ao longo do tempo, participava do progresso geral da espécie. Aos poucos, a "história filosófica" abandonava a busca por modelos éticos e políticos intemporais e se interessava pelos processos constitutivos das sociedades.

A nova proposta historiográfica mobilizou filósofos de toda Europa. O escocês William Robertson, em 1777, publicou História da América, cuja finalidade era tornar inteligível o Novo Mundo para os britânicos. Ao destacar a relevância do estudo dos povos americanos, o texto frisa que este é "uma das mais importantes e instrutivas 
pesquisas que pode ocupar o filósofo ou o historiador" (ROBERTSON, 1803, v.2, p.49), pois, para compreender a "história do espírito humano" e "atingir um perfeito conhecimento de sua natureza e suas operações, nós devemos contemplar o homem em todas as várias situações em que ele tem sido colocado". Assim, "nós devemos sempre segui-lo em seus progressos pelos diversos estágios da sociedade, [notando] como gradualmente ele avança da infância do estado da vida civil para a maturidade e o declínio". É importante observar, em cada período, "as faculdades de seu entendimento desdobrando-se" e os "vários movimentos do desejo e da afeição" (ROBERTSON, 1803, v. 2, p. 50-51). O objetivo era seguir o progresso gradual do "espírito humano" em diversos contextos e elucidar o desenvolvimento intelectual e afetivo dos homens. Robertson, como Voltaire, relacionou a "vida civil" com o aperfeiçoamento global da espécie, ainda que estivesse mais preocupado com a escala evolutiva da primeira do que com os "direitos e deveres" dos homens. Ambos enfatizaram a variedade das situações históricas e sociais. Para eles, as experiências sociais não apresentavam um quadro unitário de repetições cíclicas que pudesse servir de referência para nossas decisões no presente. O seu significado apenas seria compreendido na síntese historiográfica capaz de revelar o movimento de conjunto, o progresso. As experiências da "vida civil" eram múltiplas e comportavam oscilações, mas ganhavam sentido quando pensadas como parte da grande caminhada do progresso do "espírito humano" que as unificava. Conhecendo o percurso geral da espécie, os homens, talvez, tomassem consciência de seus "deveres e direitos" como cidadãos e, igualmente, como parte da "humanidade" eis a esperança de muitos ilustrados.

Pelo exposto, é possível afirmar que, na segunda metade do século XVIII, as Luzes começaram a esboçar a concepção contemporânea de "humanidade" na condição de conjunto de povos com experiências sociais diversas, mas com um "horizonte de expectativas" comum, o que possibilitava pensar a "história universal". Sendo assim, era necessário entender e definir o papel de cada sociedade no desenrolar dessa história, o que seria uma maneira "filosófica" de entender a multiplicidade humana.

Os textos dessa nascente "história universal" eram, na maior parte das vezes, eurocêntricos, pois apresentavam a Europa como a área do planeta onde as faculdades humanas atingiram seu grau mais elevado de desenvolvimento econômico, político e cultural (BENZONI, 2008, p. 376-378). Todavia, a nova historiografia não restringia seu campo de observação à Europa e se interessou pelas outras partes do planeta, em especial, pelos lugares onde a intervenção dos europeus foi intensa, como na América. 
Negar ou afirmar a "inferioridade" dos americanos significava pensar sua participação (ativa ou passiva) na "história universal" e sua integração ao "horizonte de expectativas" das Luzes. Como notou Cañizares-Esguerra (2011, p. 44-78), acreditavase que essa era uma forma "filosófica" de entender a experiência desses povos. Mais do que justificar ou condenar a colonização da América, tratava-se de interpretá-la como parte de um amplo movimento histórico. A pergunta era: a colonização havia contribuído de alguma maneira para o progresso da "humanidade"? Para respondê-la, a "história filosófica", entre outros aspectos, investigou, cuidadosamente, os objetivos e as ações dos colonizadores. As representações ilustradas dos colonos ibéricos na América é o objeto deste artigo.

Para investigar as características atribuídas aos colonizadores e como elas foram articuladas com a concepção de "história universal", me concentro na análise da obra do abade francês Guillaume-Thomas Raynal, História filosófica e política dos estabelecimentos e do comércio dos europeus nas duas Índias, cuja última redação ocorreu em 1780 (utilizo, aqui, uma edição de 1781 feita em Genebra). A obra teve outras duas edições em 1770 e 1774, mas me atenho à terceira versão. Nesta última, Raynal ampliou e aperfeiçoou o texto, tendo recebido a colaboração de uma equipe de filósofos, entre os quais Denis Diderot (BACAREL; BUZAREINGUES, 2009, p. 186187). O livro recebeu várias condenações: foi proibida na França pelo decreto régio de 1772 e pelo Parlamento de Paris em 1781; entrou para Index da Igreja Católica em 1774; em Portugal, foi censurado em 1773 (FURTADO; MONTEIRO, 2016, p. 736737). Na verdade, a História das duas Índias é uma espécie de enciclopédia da expansão ultramarina, contendo tanto textos técnicos a respeito de assuntos específicos quanto reflexões propriamente filosóficas (BROT, 2006, p. 303-306). Citarei Raynal como autor da obra apenas para facilitar a exposição, mas saliento que seus colaboradores foram fundamentais em sua composição.

Além da pulverização temática e da pluralidade de autores, o que por vezes implica em contradições, é importante observar as transformações do texto ao longo de suas três edições, ainda que não seja este nosso enfoque no presente artigo. No que se refere à parte dedicada à América portuguesa, Júnia Furtado e Nuno Monteiro cotejaram, cuidadosamente, as três versões e identificaram importantes alterações: “o discurso de Raynal era muito mais coerente na primeira delas, ainda que na última haja uma maior riqueza de informações empíricas", sendo que "as diferenças mais substanciais são aquelas que existem entre a primeira e a terceira edição" (FURTADO; 
MONTEIRO, 2016, p. 740), em especial, no que se refere às populações americanas e à administração colonial. Não é aqui o lugar de detalhar as distinções, mas convém atentar para algumas observações dos autores. Furtado e Monteiro (2016, p 771-773) apontam como a versão de 1780 estava menos afeita a admitir a "bondade natural" dos indígenas (mais enfatizada no texto de 1770) e acentuava tanto a leitura benigna da escravidão no Brasil quanto a visão negativa dos descendentes de portugueses nascidos na América, percepções já observáveis em edições anteriores, mas expostas de maneira mais tênue. A miscigenação, ocorrida em lugares como São Paulo e Bahia, teria sido "valorizada de forma negativa" e, em especial, no que se refere aos baianos, implicaria em uma "propensão para a indolência e inatividade". A História das duas Índias, segundo os autores, não se apresenta como um ataque agressivo à colonização portuguesa, porém, não realiza uma avaliação muito otimista dos colonos.

Furtado e Monteiro criticam os trabalhos que interpretam a obra de Raynal como um ataque vigoroso ao colonialismo europeu. Exemplo dessa interpretação, encontramos na conhecida análise de Hans Wolpe (1957) que definiu a História das duas Índias como uma "máquina de guerra" contra o mercantilismo e ação despótica das monarquias do período. Veremos que, em boa medida, a crítica procede, mas conferiu pouca atenção à complexidade das representações dos colonos ibéricos, em especial na edição de 1780, a qual me restrinjo em função dos limites e objetivos deste artigo.

\section{Colonização espanhola na História das duas Índias: barbárie e tirania}

Gerbi (1996, p. 52-54) observa que Raynal não manifestou muito entusiasmo pelas sociedades americanas pré-colombianas, ainda que, em algumas passagens, pareça inclinar-se para a imagem do "bom selvagem". Em geral, o texto caracteriza os nativos americanos como "crianças em que a razão não é ainda desenvolvida" (RAYNAL, 1781, v. 3, p. 328). Pontualmente, a obra, na sua frequente incoerência, parece simpática ao modo de vida "natural" dos nativos americanos, contraposto às mazelas da vida civilizada, como era recorrente na cultura erudita francesa desde Montaigne (1950, p. 242-246). Porém, mesmo nessas ocasiões, eles são exemplos de vida primitiva em que as faculdades humanas permanecem quase inertes. O presente dos selvagens é, para os filósofos das Luzes, “a imagem de seu passado" (DUCHET, 1971, p. 12). O futuro, em face de a presença dos europeus, eliminará suas sociedades, seja pelo extermínio, seja 
pela assimilação à vida civilizada. Para os selvagens americanos, não há "horizonte de expectativa". A "história universal", com algum pesar, prevê o seu fim, mesmo quando são definidos como exemplo do "estado natural", pois este, afinal, não é capaz de resistir ao aperfeiçoamento humano.

Para Raynal e outros filósofos das Luzes, o legado das sociedades americanas era modestíssimo: o cultivo de algumas plantas úteis (milho, batata) e a descoberta de uma ou outra técnica rústica, como o preparo dos fios de algodão. Quanto à “vida civil”, elas nada apresentavam de significativo. Os povos americanos pouco tinham a oferecer em termos evolucionais. Por isto, apesar de violenta, a presença europeia era fundamental. A colonização, se bem conduzida, colocaria o Novo Mundo em condições de desempenhar um papel histórico relevante. Furtado e Monteiro (2016, p. 774), analisando o texto de 1770, observaram muito bem que, por vezes, a representação dos indígenas - no caso, os "brasileiros" - poderiam operar "como contraponto aos europeus, descritos como corrompidos e avaros, pervertidos pela cobiça”, pois entre os primeiros "imperava a inocência, a pureza, o bem estar, a fartura e a bonança" imagem que se dissipou no texto de 1780 . Todavia, mesmo na abordagem "primitivista" de 1770, restava, na perspectiva de Raynal, algum futuro para as sociedades précabralinas? Me inclino a dizer que não. Os índios representavam o homem na sua ingenuidade perdida. Eles demonstravam que a "natureza humana" não era má, nisto residia sua força crítica, mas não oferecia uma alternativa histórica concreta.

A colonização da América, ao contrário, abria essa alternativa. O problema é que não fora bem conduzida: massacres horríveis, destruíram povos inteiros, recursos se esgotaram devido à exploração predatória, superstições irracionais foram ensinadas e impostas aos nativos. A "história filosófica" denunciava todos esses "erros" para que fossem corrigidos. Sobretudo, tratava-se de aperfeiçoar a "vida civil" que os europeus introduziram na América.

Segundo a História das duas Índias, a ação dos "aventureiros" europeus, em especial nas colônias ibero-americanas, foi uma das principais dificuldades para o estabelecimento da "vida civil". A Coroa espanhola, no início da colonização, tinha como principal interesse a descoberta de jazidas de metais preciosos. Assim, os primeiros colonizadores eram "salteadores que possuíam amor pela novidade" e manifestavam "paixão desordenada pelos metais". Eles mudavam de um lugar para outro praticando todo tipo de destruição (RAYNAL, 1781, v. 4, p. 85-86). Foram graves as consequências desse comportamento. No Peru, depois da morte de Pizarro, os 
espanhóis que lá estavam promoveram uma sangrenta "guerra civil" quando disputaram entre si o controle da área e de seus habitantes. Na ocasião, "aventureiros sem educação e nascimento" pilharam ou confiscaram os bens alheios. Observou-se "todos os excessos da licença militar que não tinha freios” (RAYNAL, 1781, v. 4, p. 69-70). No decorrer da narrativa, os primeiros conquistadores sempre aparecem atuando de modo independente e anárquico. Seus "interesses particulares" nunca se ligavam a alguma forma de interesse geral. Para estabelecer um "governo regularmente ordenado", seria necessário "tornar cidadãos os aventureiros que tinham esquecido seu país de origem" e “conheciam apenas a lei do mais forte" (RAYNAL, 1781, v. 4, p. 61).

No começo da colonização espanhola, faltava um verdadeiro governo civil. Como as leis e as autoridades não regulavam o comportamento dos "aventureiros", eles massacravam os nativos e lutavam entre si. Para Raynal, esse início caótico comprometeu o desenvolvimento colonial. Voltemos ao caso do Peru. A ferocidade da conquista e da guerra civil que a sucedeu, embruteceu os nativos, os tornou "indiferentes" quanto ao próprio futuro e "as molas de sua alma foram quebradas". A violência dos conquistadores produziu um "desencorajamento universal" e os "peruanos" entregaram-se à inatividade, pois perderam os impulsos que movem as sociedades para o progresso (RAYNAL, 1781, v. 4, p. 163-5). Os portos e as áreas de mineração experimentavam certa prosperidade no século XVIII, mas o resto da província era um "deserto terrível” em consequência das devastações dos séculos anteriores (RAYNAL, 1781, v. 4, p. 176). A colonização, portanto, não promoveu o desenvolvimento da colônia, todavia instalou uma dominação brutal que levou os "peruanos" à letargia.

Como veremos a seguir, nem sempre a análise de Raynal a respeito dos contextos coloniais foi tão amarga. Ele não caracterizou a presença europeia na América como um desastre total. No Império espanhol, a instauração dos vice-reis (em Lima e no México) e das audiências (tribunais de justiça superiores), a partir da segunda metade do século XVI, dotou as colônias de um "governo civil" talvez precário, mas que por vezes inspirava temor e fazia valer a soberania dos monarcas (RAUNAL, 1781, v. 4, p. 351-352). De qualquer forma, o caso do Peru demonstra que Raynal nunca perdeu de vista os efeitos de um início desastroso: como haveria progresso em uma sociedade dividida entre dominadores cruéis e dominados apáticos e improdutivos?

No Novo Mundo, os europeus tornaram-se mais bárbaros do que os selvagens. Por que ocorria essa "metamorfose"? Raynal procurou esboçar uma resposta: os que 
vieram para a América, em especial nos casos de Espanha e Portugal, eram os "descontentes de sua sorte", ou seja, os indigentes ou os insatisfeitos com sua condição social. Eles puderam agir com certa liberdade em virtude da "indiferença dos ministros". Os "primeiros deputados a quem se confiou a inspeção" das colônias não tinham "as luzes e as virtudes" para estabelecerem "a polícia e as leis". Nas primeiras décadas, apenas "homens indignos e ávidos, sem talento e costumes" assumiram os postos importantes no ultramar. Mesmo que os "deputados" da monarquia espanhola fossem virtuosos, seria difícil bem governar "aventureiros" intrépidos em lugares tão distantes de Madri (RAYNAL, 1781, v. 5, p. 138-139). Portanto, a colonização - em especial a espanhola e a portuguesa - iniciou-se como uma grande pilhagem conduzida por conquistadores sem nenhuma virtude cívica e fora do controle dos governos metropolitanos. Ao logo do tempo, seus descendentes se transformaram em "tiranos":

O império imenso que Castela fundou na América meridional foi subordinado a um único chefe (o vice-rei em Lima). As partes afastadas do centro da autoridade eram necessariamente abandonadas ao capricho, à inexperiência e à rapacidade de uma multidão de tiranos subalternos. Nenhum espanhol, nenhum índio, seria louco de percorrer milhares de milhas para reclamar uma justiça que seguramente não obteria. A força do hábito, que com frequência sufoca a voz da razão e governa de modo absoluto tanto os Estados como os indivíduos, impedia que se abrisse os olhos para o princípio seguro de tantas calamidades (RAYNAL, 1781, v. 4, p. 297).

O imenso tamanho do império, a precária e enganosa centralização administrativa e os hábitos bárbaros possibilitaram que "tiranos subalternos" continuassem a cometer injustiças. $\mathrm{Na}$ avaliação da História das duas Índias, a monarquia espanhola foi incapaz de instaurar na América uma "vida civil" na qual as instituições e as leis limitassem as ambições e a violência da elite colonial. Esta dominava as regiões distantes, agindo de acordo com seus "caprichos" e fora do controle das instâncias governamentais. O problema mais grave não era o "despotismo" da Coroa, todavia a independência dos poderes regionais, teoricamente "subalternos", mas, na verdade, livres de qualquer regulação de Madri ou de Lima. Temos aqui a imagem de um império fragmentado, desconexo, entregue às paixões de suas elites periféricas, apesar da aparente autoridade dos vice-reis. O verdadeiro e calamitoso "princípio" de governo era o poder excessivo dos pequenos "tiranos" - que descendiam dos "aventureiros" - e a inoperância do poder central. Se nos textos sobre a América inglesa, Raynal denunciou o "despotismo" da metrópole, leitura que impactou as elites latino-americanas (VENTURA, 1988), nos capítulos sobre a América espanhola, ele 
criticou, ao contrário, a incapacidade da Coroa em controlar seus principais súditos americanos.

Todavia, convém notar que a fragmentação do poder no mundo colonial, na análise de Raynal, era uma tendência da própria expansão ultramarina e não se restringia ao Império espanhol. Expondo as alternativas de recuperação do Império holandês na Índia, já em franca decadência no final do século XVIII, Raynal salienta que "toda colônia, supondo a autoridade em um lugar e a obediência em outro local distante, é um estabelecimento por princípio vicioso. É uma máquina cujas molas se relaxam, se quebram sem cessar e é preciso reparar continuamente" (RAYNAL, 1780, v. 1, p. 477). Assim, a distância do poder metropolitano acabava por corromper a ordem colonial. Na América ibérica, o problema parecia particularmente grave, pois os "aventureiros" e seus sucessores tiveram muita liberdade, impedindo a existência de uma ordem civil regular. Para modificar essa situação, era necessário aperfeiçoar o controle da Coroa sobre o mundo colonial, ou seja, os colonizadores ferozes deveriam voltar a ser cidadãos regidos por leis e autoridades públicas.

No início do capítulo X, que trata dos "estabelecimentos das nações europeias" nas Antilhas, Raynal volta a criticar a conduta dos europeus no Novo Mundo. O texto não se refere especificamente aos espanhóis. A "metamorfose do europeu expatriado" aparece como fenômeno comum a todas as experiências coloniais:

\begin{abstract}
Homens civilizados - tendo vivido em sua pátria submetidos a governantes, senão sábios, ao menos antigos; sendo todos criados em lares onde recebiam lições e alguns exemplos de virtude; crescendo todos em cidades policiadas, onde o exercício de uma justiça severa os acostumou a respeitar seus semelhantes - teriam todos uma conduta que proscreveu igualmente a humanidade, seus interesses, sua segurança, as primeiras luzes da razão e se tornaram mais bárbaros que os selvagens? Bom Deus, serei obrigado a traçar um quadro apavorante! (RAYNAL, 1781, v. 5, p. 138).
\end{abstract}

Mesmo sendo uma pergunta, o que possibilita margem para a dúvida, a passagem sugere que "todos" os colonizadores europeus decaíram na barbárie, abandonando a "humanidade" e os preceitos do mundo civilizado. Na contramão do "horizonte de expectativas" das Luzes, eles regrediram. Para Raynal, trata-se de um fenômeno "estranho" que a "história filosófica" precisa investigar. Suas especulações apontam, mais uma vez, para a ausência no mundo colonial de uma instância superior capaz de regular as relações entre os homens, fosse um "governo" eficaz ou a "opinião pública”. Assim, ele se pergunta se o europeu, uma vez liberto dos constrangimentos das leis e dos costumes, não é mais perverso do que o selvagem. Ora, 
seres muito descontentes de sua sorte; destituídos de recursos em seu próprio país; indigentes ou ambiciosos o suficiente para desdenhar a vida e se expor a perigos e trabalhos infinitos com a esperança vaga de uma fortuna rápida; sob um outro céu, distante da vindita pública e dos olhares inquisitivos de seus concidadãos; não teriam no fundo de seus corações o germe fatal de uma depredação que se desenvolveu com uma celeridade e um furor inacreditáveis quando nem pudor nem temor detiveram seus efeitos? (RAYNAL, 1781, v. 5, p. 138-139).

Os insatisfeitos do Velho Mundo tinham o "germe" da barbárie? É o que o texto insinua. A civilização europeia não eliminara as raízes da ferocidade humana. Ela continuava a produzir "indigentes e ambiciosos" que, sem o "pudor" da "opinião pública" e o "temor" do "governo", podiam agir como feras violentas. As sociedades europeias criavam personagens potencialmente perigosos. Na ausência da coerção do Estado, da família ou dos costumes, eram capazes de todas as atrocidades.

Por outro lado, Raynal reconheceu que, além dos "aventureiros" e dos "tiranos" locais, outro tipo de colonizador foi importante para o início da expansão ultramarina: o missionário religioso. Ele destaca, em especial, a atuação dos jesuítas e do dominicano espanhol Bartolomeu de Las Casas. Neste artigo, não teremos espaço para analisar as numerosas passagens a respeito dos jesuítas que merecem um estudo à parte. Las Casas, por sua vez, aparece como uma espécie de contraponto dos "aventureiros", tendo em vista que, já em meados do século XVI, denunciou, energicamente, a brutalidade de seus compatriotas. A História das duas Índias retoma as denúncias do missionário dominicano para demonstrar a violência da conquista. Ao lado de outros "defensores dos índios", Las Casas ajudou a estabelecer a famosa "lenda negra", cuja atuação dos espanhóis na América era descrita como uma sequência de horrores. Seu Relato da destruição das Índias (1552) já circulava em várias línguas pela Europa renascentista em edições com horripilantes gravuras. Convém lembrar, porém, que Las Casas "não pôs em dúvida a missão da Espanha nas Índias”, apenas pretendia que ela se realizasse "por meios pacíficos em vez de sê-lo por coerção, e pela Coroa e pelos missionários e não pelos colonos" (ELLIOT, 1998, v. 1, p. 305-306). Ele preocupava-se, sobretudo, com a cristianização dos povos americanos. Era uma tarefa que os espanhóis poderiam realizar com sucesso, pois os índios, a seu ver, já possuíam traços cristãos: eram "doces", "decentes", "meigos", "pacíficos", "muito obedientes" e "sem maldade ou duplicidade" (TODOROV, 1991, p. 160-161). Para ele, a Santa Sé, que tinha "poder sobre os infiéis", havia escolhido o rei espanhol para "o ministério da pregação da fé nas 
Índias", o investindo “da suprema soberania”. Assim, defendeu apaixonadamente os índios, mas assumiu uma "ideologia colonialista" (TODOROV, 1991, p. 168-170). O diagnóstico de Las Casas, portanto, já continha a ideia de que a monarquia permitia a brutalidade dos conquistadores e não ofereceria aos americanos o maior benefício proveniente do Velho Mundo: o cristianismo e a salvação das almas. Os índios não eram tratados como verdadeiros "vassalos" do monarca espanhol.

A historiografia da Luzes, em boa medida, assimilou a "lenda negra" e os protestos de Las Casas (DUCHET, 1971, p. 194-199). A História das duas Índias louvou sua coragem e sua persistência em denunciar o caráter brutal da conquista (RAYNAL, 1781, v. 4, p. 340). Ele lutou para "civilizar" os nativos "sem guerra, sem violência e sem escravidão", criando núcleos coloniais nos quais pretendia que os nativos convivessem com imigrantes europeus laboriosos e piedosos e, pelo exemplo, assimilassem o cristianismo e o trabalho regular. Todavia, Raynal avaliava que Las Casas fracassou, pois não recebeu apoio substancial da Coroa, afinal, "os ambiciosos que governam os impérios consomem os povos como uma mercadoria" e consideram quiméricos os planos que pretendam tornar os homens "felizes". Também teve muita dificuldade para recrutar bons artesãos e agricultores para seus núcleos coloniais, já que os "cidadãos pacíficos" não manifestavam o ardor necessário para enfrentar o desafio de viver no Novo Mundo (RAYNAL, 1781, v. 4, p. 106-107). A História das duas Índias sugere, como é possível notar, que a colonização, nas condições históricas do século XVI, só poderia ser conduzida por "aventureiros" ambiciosos ou missionários abnegados. Todavia, o texto assinala as grandes dificuldades enfrentadas por estes últimos e, de modo mais enfático, salienta a impotência e a ingenuidade de Las Casas ao tentar implementar seu projeto missionário: as monarquias da Renascença nem pretendiam, nem poderiam implantar estabelecimentos coloniais humanitários e pacíficos, pois a exploração violenta - a redução dos homens à condição de "mercadoria" - estava no cerne das motivações oficiais e particulares do expansionismo europeu.

Las Casas foi visto com simpatia e admiração por Raynal (MOURREAU, 1999, p. 169), mas este não se limitou a repetir a "lenda negra" e tomou certo distanciamento crítico do missionário dominicano. Avalia que a dedicação e o senso moral de Las Casas e de outros missionários foram insuficientes para corrigir os efeitos desastrosos de um processo colonial baseado na exploração e na pilhagem dos povos americanos. Só um amplo conjunto de medidas bem articuladas poderia reverter o quadro. Não 
bastava boa vontade, caridade ou firmeza moral; não bastava contar com bons cristãos como Las Casas. Era necessário compreender profundamente a história dos impérios, identificar seus principais "erros" e pensar a longo prazo. Instaurar a "vida civil" no ambiente americano exigia um considerável esforço intelectual e político.

Em contrapartida, os problemas americanos também derivavam da incapacidade do Velho Mundo em formar homens que não tivessem, em seus "corações", o "germe fatal" da destruição. A crítica à colonização espanhola desemboca no questionamento da própria "vida civilizada" europeia, que alimentava ambições desmedidas e não oferecia os recursos necessários para todos os seus membros. Os "aventureiros", flagelos da América, eram homens formados nessas condições. Quando atuavam fora do controle das autoridades públicas, não poderiam ter objetivos muito elevados:

A ideia de fundar colônias em regiões distantes e de aumentar o domínio de seu soberano jamais se apresentou nitidamente ao espírito de algum desses primeiros aventureiros. O Novo Mundo lhes pareceu mais uma rica presa que se poderia devorar do que uma conquista a ser cuidada? [...] É possível, mesmo em nossos dias, reger povos separados da metrópole por mares imensos como súditos sujeitos ao cetro? (RAYNAL, 1781, v. 5, p. 139).

O problema não se resumia à corrupção dos "aventureiros". As metrópoles eram sociedades injustas, nas quais o receio de sanções sociais tolhia a agressividade dos miseráveis e dos ambiciosos. O sentimento de "humanidade" não os guiava, não penetrava profundamente em seu mundo interior. Não dilaceravam seus semelhantes na Europa apenas por medo e pudor, mas estavam inclinados a fazê-lo, assim que a situação propícia se apresentasse, como na desgovernada América. A "vida civil" europeia se fundamentava em atos coercitivos. Poucos eram os "cidadãos" verdadeiramente esclarecidos e orientados pelos princípios do bem comum. A ordem dependia, acima de tudo, da força repressiva do Estado e de constrangimentos sociais. Assim, o desastre americano revelava as fragilidades do processo civilizador no Velho Continente.

No século XVIII, a confiança no progresso era bem menor do que se acredita atualmente. Sem indivíduos "virtuosos" e soberanos ilustrados, o progresso seria consistente? Não estaria sempre ameaçado quando os homens estivessem livres de fatores coercitivos?

O lado sombrio do "horizonte de expectativas" das Luzes se deixa entrever nas linhas da História das duas Índias. Elas anunciam o risco de retrocesso da civilização e a angústia dos ilustrados diante do futuro. Para evitar o retrocesso, era necessário 
garantir uma "vida civil" controlada por soberanos capazes de impor leis estáveis. Sem a intervenção do poder político, o progresso, em qualquer sociedade, estava ameaçado. Certamente, a história era entendida como "totalidade aberta" para o futuro, como afirma Koselleck, mas o aperfeiçoamento contínuo do homem estaria garantido? "Filósofos", como Raynal e seus colaboradores, acreditavam no lento esclarecimento da espécie, mas as dúvidas persistiam. Era imprescindível criar meios sociais e políticos para assegurar a efetividade dos princípios ilustrados. Sem isso, como na América, não haveria progresso contínuo e duradouro. A formação de homens "virtuosos" e de instituições que os apoiassem exigia um poder político em condições de implementar medidas consistentes. Caso contrário, como demonstrava a história de Las Casas, os melhores projetos seriam infrutíferos.

Para compreender melhor as carências da colonização da América, é preciso esclarecer o que significava "virtude" no final do século XVIII. No verbete "Virtude" do Dicionário filosófico, Voltaire procurou definir os princípios que deveriam orientar o homem público ilustrado:

\footnotetext{
O que é virtude? Beneficiência para com o próximo. [...] Nós vivemos em sociedade, portanto, só é verdadeiramente bom para nós o que faz o bem da sociedade. Um solitário será sóbrio, piedoso, vestirá um cilício; muito bem, ele será santo, mas eu o chamaria virtuoso apenas quando realizasse um ato de virtude proveitoso para os outros homens. [...] Entre os homens, a virtude é o um comércio de benefícios: quem não participa deste comércio não deve ser contado [entre os virtuosos] (VOLTAIRE, 1964, p. 371-372).
}

A "virtude" como "comércio de benefícios" não foi uma formulação unânime entre os ilustrados. Montesquieu (1949, v. 1, p. 4), por exemplo, definiu "virtude política", no Espírito das leis, como "amor à pátria". Ela seria fundamental nas repúblicas que exigiam cidadãos inteiramente voltados para o bem comum (a "pátria"), a ponto de colocarem suas ambições pessoais em segundo plano. Afinal, o regime republicano não comporta um poder coercitivo superior ao próprio conjunto de cidadãos. Em Voltaire, a "virtude", antes de ser um princípio afetivo norteador da vida republicana, é a capacidade e a disposição de promover o "bem da sociedade" e auxiliar o próximo. Perspectivas distintas, mas com ao menos uma convergência: para os dois filósofos, "virtuoso" é alguém que transcende seus interesses privados em favor dos interesses comuns, ou seja, não se limita a buscar unicamente o seu próprio benefício, mas, sim, almeja compartilhar a felicidade com seu grupo social. A "virtude" dos ilustrados só se efetiva na experiência coletiva, na "pátria", nas relações públicas - no “comércio" entre indivíduos - e nunca na solidão. 
Ora, vimos que esse interesse pelo bem comum era, para Raynal, o que fazia de Las Casas o melhor dos colonizadores. Em contrapartida, os "aventureiros", longe da "pátria", não manifestavam "humanidade" e pouco se importavam com o sofrimento alheio ou com a vida coletiva. Por necessidade ou por ambição, atuavam fora de qualquer controle público, alheios a todos os sentimentos que fundamentavam a ordem social e, assim, comprometiam, no sentido de Voltaire, o "comércio de benefícios" entre os povos. Nos termos dos pensadores das Luzes, eles careciam de "virtude", pois desprezavam, completamente, qualquer forma de bem comum. Sua "ferocidade" derivava da ausência de fatores associativos - fossem afetivos ou coercitivos - que oferecesse uma perspectiva de ação coletiva e garantisse a "vida civil". Mesmo depois de estabelecidos na América, eles, por muito tempo, continuavam a agir de modo predatório e egoísta, ou seja, não constituíam uma verdadeira sociedade.

Em termos cívicos, a colônia espanhola era, para os filósofos do século XVIII, uma espécie de "monstro", um amálgama social ainda disforme. Eles a concebiam como um ambiente rude, no qual o europeu sem "virtude" perdia de vez a "humanidade" e, entregue às próprias paixões, voltava a ser fera. No caso dos bons colonizadores, eles não encontravam, naquele ambiente bárbaro e incivil, os meios e as condições para agir de modo eficiente em favor do bem comum. Las Casas foi incapaz de "civilizar" os índios - na verdade, ele queria cristianizá-los - porque os “aventureiros" os exploravam e expropriavam de modo cruel. Os monarcas permitiam a ação desses dominadores, pois queriam se apropriar, rapidamente, das mercadorias do ultramar e tinham dificuldade de recrutar outro tipo de colonizador. A ausência de "vida civil" na América era produto de todas essas circunstâncias. Outros fatores ainda intervinham, como a existência de monopólios comerciais e o poder da Igreja, temas pouco lembrados neste trabalho em razão de suas limitações. A História das duas Índias, para explicar as dificuldades do império espanhol, procurou articular todos esses problemas.

Ao tratar do Império português, como veremos a seguir, Raynal não abanou o tema da "vida civil" e das "virtudes" que ela exige. Todavia, nem todos os intérpretes notaram essas preocupações. No prefácio da edição brasileira do capítulo 9 da História das duas Índias, dedicado à América portuguesa (edição de 1780), Berenice Cavalcante (in RAYNAL, 1998, p. 23-24) caracteriza a "história filosófica" de Raynal como "crítica à tirania e à opressão em todas as suas manifestações", pois a obra defende o "princípio da liberdade". Para a autora, porém, Raynal restringiu ao "monarca esclarecido as iniciativas reformadoras" e, portanto, "a questão da liberdade não se 
confundiria com o exercício das virtudes cívicas e, ao menos ainda com a noção de direito natural tal como formulado no século XVIII” (CAVALCANTE, 1998, p. 24-25). Não estou de acordo com essa última afirmação. Como procurei demonstrar acima, as "virtudes" tinham papel importante no texto de Raynal. Do seu ponto de vista, na conquista da América, o que faltou aos ibéricos foi justamente "virtude" e respeito pelo "direito natural" dos nativos. A colonização só favoreceria a "humanidade" e estabeleceria uma verdadeira "vida civil" se o poder público trabalhasse para promover a "virtude" e o "direito natural" - sem isso, nenhuma "reforma" seria benéfica. No entanto, os colonos poderosos tornaram-se pequenos "tiranos" em razão de sua independência. Para que deixassem de oprimir os americanos, era preciso tolher sua liberdade de ação. O fortalecimento do poder monárquico, no programa de Raynal, estava relacionado à necessidade de controlar esses inquietos descendentes dos "aventureiros". A busca pelo bem comum, o fundamento da "virtude" para boa parte dos ilustrados, só seria viável se a violência e a voracidade dos "tiranos" locais fossem limitadas. Eis a condição indispensável para haver progresso. Vejamos como esse conjunto de preocupações se exprimiu na história da América portuguesa.

\section{América portuguesa: dilemas e sinais de progresso}

Furtado e Monteiro (2016, p. 772), com razão, mas com certo exagero, propuseram que "a visão [de Raynal] da administração portuguesa é globalmente pouco crítica e torna-se quase apologética na edição de 1780”. Todavia, em diversos aspectos, a análise da colonização portuguesa aproxima-se do quadro traçado para a América espanhola.

Segundo a História das duas Índias, como outros europeus, os portugueses, logo que chegaram ao Novo Mundo, se comportaram como o "tigre domesticado que retorna à floresta", manifestando o mesmo "furor" e "sede de outro" dos espanhóis. Atacaram os nativos, invadiram suas terras e os escravizaram, abandonando o pacífico “comércio", um dos pilares da civilização (RAYNAL, 1781, v. 5, p. 1-3). Nas primeiras décadas do século XVI, a Coroa lusitana deixou sua colônia "aos furores e ao capricho de alguns salteadores" (RAYNAL, 1781, v. 5, p. 20). Os jesuítas cristianizavam os índios de forma pacífica, mas, constantemente, precisavam protestar contra a escravidão indígena, que estava proibida, porém continuava a existir em decorrência do "espírito de independência" dos colonos. A Coroa, como na América espanhola, tinha um controle 
limitado de sua colônia e "não lhe era permitido querer tudo que era justo" (RAYNAL, 1781, v. 5, p. 67). Jesuítas à parte, os portugueses nunca implementaram um programa civilizatório consistente e bem definido. Apesar da miscigenação com portugueses e africanos, os povos americanos, pelo menos até meados do século XVIII, "não mudaram de caráter", pois "não se trabalhou para esclarecê-los" e para vencer sua “preguiça natural” (RAYNAL, 1781, v. 5, p. 70).

Em contrapartida, nas principais cidades, a ordem social parecia comprometida: “Os costumes são no Rio de Janeiro o que são na Bahia e em todos os países de minas. Nota-se os mesmos roubos, as mesmas traições, as mesmas vinganças, os mesmos excessos de todos os gêneros, e sempre a mesma impunidade" (RAYNAL, 1781, v. 5, p. 86-87). Deixando de lado a questão da economia mineradora, outro assunto que mereceria análise mais detalhada, vemos que Raynal diagnosticou a livre manifestação das paixões como um dos principais problemas da América portuguesa. Para ele, a brutalidade - expressa nas vinganças, traições ou caçadas de índios - predominava em um ambiente no qual os "excessos" dos indivíduos não encontravam limite na "vida civil". Nem as relações interpessoais urbanas, nem o Estado regulavam os impulsos passionais que se exprimiam de maneira aberta e sem constrangimentos legais ou consuetudinários. O progresso da civilização só poderia patinar quando governa o mais forte, não o direito.

$\mathrm{Na}$ América portuguesa, como na espanhola, os colonos tinham amplo espaço para operar fora do controle das autoridades metropolitanas. No período em que se instalaram no Novo Mundo, os ibéricos não seguiram "princípios" racionais e equitativos. Segundo o oitavo capítulo da História das duas Índias, se um estrangeiro se estabelece em um país povoado, não pode exigir dos locais nada além de "asilo" e hospitalidade. Caso se apodere violentamente dos bens dos nativos, "se transforma em ladrão e assassino" (RAYNAL, 1781, v. 4, p. 245-246). Mas a realidade é outra em um lugar parcialmente ocupado (como as costas atlânticas da América do Sul):

Se o lugar é em parte deserto e em parte ocupado, a parte deserta é minha. Eu posso tomá-la por meio de meu trabalho. Se o antigo habitante, sendo bárbaro, vem subitamente derrubar minha cabana, destruir minhas plantações, pilhar meus campos, eu poderia repelir sua invasão e usar a força. Eu posso estender o meu domínio até os confins dos domínios dele. [...] Tudo o que ele pode exigir de mim, é que eu seja um vizinho pacífico e que meu estabelecimento não constitua uma ameaça para ele. Todo povo está autorizado a garantir sua segurança presente e futura (RAYNAL, 1781, v. 4, p. 247). 
Comportando-se como "tigres", agindo sem "humanidade" e ignorando os "princípios" expostos acima, espanhóis e portugueses ameaçaram os nativos. Qualquer potência europeia tinha o direito de se fixar nas terras quase desertas da América do Sul e, se atacada, poderia organizar sua defesa sem ferir a justiça natural. Não há dúvida quanto à proximidade desse argumento com o quinto capítulo (\$26-30) do Segundo tratado sobre o governo, obra de John Locke (2001, p. 407-412): segundo o pensador inglês, quando o homem "remove" um objeto do estado natural e o modifica com seu trabalho, reúne ao objeto algo que é seu, transformando-o em sua propriedade. Seguindo o argumento de Locke, a terra deserta trabalhada pelo colono europeu era sua legítima propriedade. Todavia, ele não tinha um motivo justo para ameaçar a segurança dos selvagens e tomar seus bens. Em vez de ferir os direitos "naturais" dos povos americanos, os europeus deveriam ter promovido trocas "perfeitamente livres" com eles. Atacando os nativos, os ibéricos instauraram, na América, o "estado de guerra" descrito por Locke (2001, p. 395-397) e romperam premissas fundamentais do "comércio de benefícios" e da "vida civil". A brutalidade e as injustiças da conquista explicavam, em grande medida, as deficiências das sociedades coloniais.

Lembra Kenta Ohji (2008, p. 69) que, para Raynal e seus colaboradores, “a civilização dos selvagens [...] se apresenta, antes de qualquer coisa, como um problema maior". Esse "horizonte de expectativa" ilustrado para o Novo Mundo, até o século XVIII, havia sido frustrado pela colonização ibérica. Os selvagens estavam destinados a desaparecer, mas não era justo e salutar que fossem eliminados à força. Era necessário incorporá-los, pacificamente, ao "comércio de benefícios" da "vida civilizada". A preocupação central com a "civilização dos selvagens" explica o otimismo da História das duas Índias com a Lei da Liberdade dos Índios, de 1755, e o Diretório dos Índios, de 1757, propostos por Pombal para a América portuguesa. As novas leis determinavam que os indígenas se tornassem proprietários com responsabilidades civis. As medidas "dividiram os espíritos", mas o texto inclina-se para a opinião de que os nativos, transformando-se em "senhores de suas ações", tenderiam a ser "superiores em inteligência e indústria aos mantidos em tutela perpétua" (RAYNAL, 1781, v. 5, p. 7071). Eram decisões que poderiam redimir e regenerar um processo colonial perverso (FURTADO; MONTEIRO, 2016, p. 766-770). Os portugueses, com a política indigenista de Pombal, estavam reconhecendo e corrigindo seus "erros".

Mas existiam outros sinais positivos na colonização portuguesa? 
Na História das duas Índias, o mundo colonial não se resume à barbárie. O texto contempla diversas contingências históricas e apresenta avaliações surpreendentes. Em geral, representa os "aventureiros" como empecilhos para o estabelecimento da "vida civil" na América, mas eles também aparecem em outros registros.

Atentemos para o caso dos "paulistas". Raynal sabia que eles eram os principais caçadores de índios do "Brasil", pois escravizavam os nativos mesmo com as proibições da Coroa. Apoiados em seu "governo municipal" (deve ser uma referência à Câmara de São Paulo), eles, mais do que quaisquer outros colonos, manifestavam aquele "espírito de independência" a pouco referido. São Paulo e Maranhão, onde "não existiam ricas culturas", foram as áreas nas quais o cativeiro indígena se manteve por mais tempo (RAYNAL, 1781, v. 5, p. 68).

Considerando passagens anteriores de Raynal, seria de se esperar um julgamento bem negativo dos "paulistas". Entretanto, o capítulo dedicado à "província de São Paulo" na edição de 1780 causa surpresa. A cidade de São Paulo, segundo o texto, foi fundada por "malfeitores com os quais Portugal havia infestado as costas do mundo". Quando a Coroa tentou submetê-los, eles se refugiaram no interior e fundaram a cidade em lugar afastado, "onde as leis não os atingiam". "Outros bandidos” e mestiços da área se reuniram a esse grupo de rebeldes, criando uma "nova república" quase autônoma. Até aí, o texto descreve os "paulistas" recorrendo ao mesmo conjunto de representações que define os bárbaros "aventureiros" da América hispânica, mas o sentido dessas representações muda a partir desse ponto. Os "paulistas", recusando a ociosidade típica dos senhores de escravos, "percorreram o interior do Brasil de uma extremidade à outra" e abriram imensas possibilidades para a colonização portuguesa. O que explica esse comportamento? Segundo a História das duas Índias,

\footnotetext{
[...] tudo convidava os paulistas a viverem na ociosidade, no repouso e na moleza. Uma certa inquietude, natural de bandidos corajosos; a vontade de dominar que segue de perto sua independência; os progressos da liberdade que conduzem a ambicionar um nome; talvez todos esses motivos reunidos lhes conferiram outras inclinações (RAYNAL, 1781, v. 5, p. 90).
}

Características consideradas bastante negativas no caso dos "aventureiros" do Peru, recebem, aqui, outra leitura. A "inquietude" do bandido, a "vontade de dominar", a ambição de nomeada, figuram como fatores capazes de impulsionar os "paulistas" a fim de explorar terras desconhecidas. Seguramente, eram "homens atrozes" e promoveram "devastações" e "crueldades". Porém, "em meio a tantos horrores, se 
formava, sob um governo municipal, alguns povoados que é preciso ver como o berço de todos os estabelecimentos que mantêm Portugal em suas terras" (RAYNAL, 1781, v. 5, p. 91). O tom paradoxal é notório: os rebeldes "paulistas" possibilitaram aos portugueses imensos e importantes territórios. Sua inquieta independência é apresentada como algo positivo, pois contribuiu de modo decisivo para a expansão da colônia, estendendo-a para além da costa atlântica. Ora, nem todas as realizações dos "aventureiros" foram destrutivas. Para a "história filosófica", a violência e a rebeldia, por vezes, ajudaram a estabelecer novas e promissoras circunstâncias históricas. Mesmo a ação atroz e cruel dos "aventureiros" pode, em alguma medida, ser resgatada pelo "horizonte de expectativas" das Luzes.

Em contrapartida, atente-se para a expressão "sob o governo municipal”. É uma clara referência à ação autônoma dos "paulistas" coordenada pela Câmara de São Paulo. A princípio, eles agiram fora do controle da Coroa, acentuando a fragmentação atestada por Raynal em todo Novo Mundo. Quanto às novas colônias que fundaram, eram "pequenas repúblicas destacadas, de algum modo, da grande". Em um segundo momento, pouco a pouco, se sujeitaram "a uma autoridade que nunca desconheceram por completo" - "com o tempo, todos os paulistas foram submetidos à Coroa" (RAYNAL, 1781, v. 5, p. 91). Assim, a independência paulista foi decisiva para a ocupação de novas e importantes áreas, criando "repúblicas" autônomas pelo continente. Mas essas iniciativas pioneiras ganharam todo seu significado histórico quando a Coroa, paulatinamente, conseguiu colocá-las sob seu controle. O "governo municipal" ofereceu um ponto de partida para a interiorização do governo português, mas foi a submissão ao poder central que possibilitou completar o processo.

Um outro exemplo de uma avaliação mais otimista dos primeiros colonizadores aparece nas páginas dedicadas à Santa Catarina. Segundo a História das duas Índias, em meados do século XVII, apenas "alguns vagabundos" ocupavam a ilha: "esses aventureiros reconheciam vagamente a autoridade de Portugal”. Sem respeitar as leis monopolistas da monarquia, recebiam em seu porto embarcações de toda parte da Europa, vendendo alimentos em troca de alguns poucos produtos. Isolados e independentes, desprezavam o dinheiro e as comodidades da civilização. Raynal não os define como "virtuosos", mas pelo menos eles não manifestavam os excessos passionais dos conquistadores acima descritos, pois estavam satisfeitos com o que "a natureza lhes oferecia". Diferentemente da maior parte dos "aventureiros" ibéricos, os de Santa Catarina, em razão de sua vida simples e da ausência de grandes ambições, não se 
comportavam de modo bárbaro e predatório. Os hispânicos agiam como "tiranos", ou seja, não eram apenas independentes e livres, visto que controlavam os mecanismos locais de poder e usurpavam a soberania dos monarcas. Os "vagabundos" de Santa Catarina não obedeciam a Coroa, mas não estabeleceram na colônia uma forma de dominação que impedisse o Estado de assimilar e controlar os povos da América. Em suma, eles não atacaram e escravizaram os americanos, também não lhes roubaram os bens, se limitaram a ocupar as áreas "desertas".

A maneira como termina o capítulo sobre Santa Catarina é esclarecedora:

\begin{abstract}
Por vezes a gentalha e a escória das sociedades policiadas podem formar uma sociedade bem ordenada. É a iniquidade de nossas leis, é a injusta repartição dos bens, são os abusos do poder que frequentemente fazem os rebeldes e os criminosos. Reúna todos esses infelizes que, com frequência, um rigor ultrajante baniu de seus lares e dê-lhes um chefe intrépido, generoso, humano, esclarecido, dócil e racional. Se as necessidades o fizeram guerreiro, ele tornar-se-á conquistador; para se engrandecer, fiel seguidor das leis para consigo mesmo, violará os direitos das nações, tal como os romanos. Se, na falta de um condutor hábil, ele é abandonado à mercê da sorte e dos acontecimentos, ele será mau, inquieto, ávido, sem estabilidade, sempre em conflito consigo mesmo ou com seus vizinhos, tal como os paulistas. Enfim, se ele pode viver mais facilmente dos frutos da terra ou da cultura e do comércio que da pilhagem, terá as virtudes próprias de sua situação, as inclinações doces que inspira o interesse racional pelo bem-estar. Civilizado pela felicidade e segurança de uma vida tranquila, respeitará em todos os homens os mesmos direitos de que ele goza, e promoverá a troca da superabundância de suas produções com as comodidades de outros povos, tal como os refugiados de Santa Catarina (RAYNAL, 1781, v. 5, p. 88-89).
\end{abstract}

A passagem oferece uma síntese da argumentação da História das duas Índias. Exprime as três alternativas históricas que se oferecem para os "aventureiros": ser "conquistador", como os romanos e boa parte dos portugueses e espanhóis; ser explorador inquieto e ambíguo, como os "paulistas"; ser "mercador" tranquilo e pacífico, como os catarinenses. Apenas no último caso, Raynal identificou um comportamento plenamente racional e favorável à civilização. O que "civiliza" é "a felicidade e a segurança de uma vida tranquila”, algo impossível para quem precisa sobreviver em um ambiente no qual a desigualdade social e as leis são injustas, onde o "abuso de poder" produz criminosos. Como em outras passagens, a História das duas Índias responsabiliza as sociedades metropolitanas pelo comportamento bárbaro e violento dos "aventureiros". Na América e na Europa eles não puderam viver com "felicidade e segurança", precisaram enfrentar contextos sociais injustos e instáveis e, portanto, agiram de maneira brutal e predatória para adquirir poder e posição social, comprometendo os "direitos" de seus semelhantes. Sendo assim, não praticaram o 
"comércio de benefícios" dos homens "virtuosos". Mergulharam na barbárie, pois lhes foi negado as maiores vantagens da civilização: segurança, justiça, igualdade de direitos, trocas compensadoras, enfim, "humanidade".

Todavia, para Raynal, existia a possibilidade de transformar o "aventureiro" da injusta "sociedade policiada" em um agente civilizador. O produto histórico de suas ações dependeria das circunstâncias e dos governantes, ou seja, era possível evitar que se transformasse em criminoso. Se ele pudesse trabalhar e trocar seus produtos de maneira vantajosa, se não fosse oprimido pelos "abusos" dos soberanos ou dos pequenos "tiranos", se estivesse protegido de malfeitores, se o poder público limitasse seus excessos, ele poderia ser, talvez, um homem "virtuoso", agindo em favor do bem comum. O progresso da América - "horizonte de expectativas" da "histórica filosófica" de Raynal - era viável. Em casos pontuais, como em Santa Catarina, vislumbrava-se sua realização. Mas era necessário encontrar "chefes humanos e racionais" que conduzissem os marginalizados da Europa e lhes oferecessem nova perspectiva de vida.

Transformar a "escória" da Europa em homens "virtuosos" na América - eis a tarefa que a "história filosófica" de Raynal projetou para os governos coloniais. Tarefa difícil, mas indispensável. Se não fosse realizada, os "aventureiros" e seus descendentes transformariam a América em uma imensa área pouco produtiva de população apática, dividida entre "tiranos", rebeldes e turbulentos, como já ocorria, aliás, em boa parte do continente. Nessas condições, a "vida civil”, fundamento do progresso e da civilização, seria precária. Como em outros contextos, para a "história filosófica", o aperfeiçoamento só se realizaria como a superação das experiências existentes.

Ainda vivemos a expectativa da instauração de uma "vida civil" pacífica e justa nas sociedades ibero-americanas. O que herdamos das Luzes? Expectativas ou algo mais? 


\section{REFERÊNCIAS}

BACAREL, Gilles e BUZAREINGUES, François. Guillaume-Thomaz Raynal, historien e philosophe français du XVIIIe siècles. Communication présentées en 2009, Académie des Science ey Lettres de Montpellier, p.185-200, 2009.

BENZONI, Maria Matilde. The idea of Europe and the "Dispute of the New World". Some reflections between history and historiography. History of European Ideas, n. 34, p. 375-382, 2008.

BROT, Muriel. Les dictionnaires de l'Histoire de deux Indies. Dix-huitième siècles, v. 38, n. 1, p. 303-317, 2006.

CAÑIZARES-ESGUERRA, Jorge. Como escrever a história do Novo Mundo. Histórias, epistemologias e identidades no mundo atlântico do século XVIII. São Paulo: EDUSP, 2011.

CAVALCANTE, Berenice. Dilemas e paradoxos de um filósofo iluminista. IN: RAYNAL, Guillaume-Thomas. O estabelecimento dos portugueses no Brasil. Livro nono da História filosófica e política das possessões e do comércio dos europeus nas duas Índias. Brasília: Editora UnB; Rio de Janeiro: Arquivo Nacional, 1998, p. 11-33.

DUCHET, Michèle. Anthropologie et histoire au siècle des Lumières. Paris: François Maspero, 1971.

ELLIOT, John T. A Espanha e a América nos séculos XVI e XVII. BETHELL, Leslie (org.). História da América Latina. A América Latina colonial. São Paulo: EDUSP; Brasília: Fundação Alexandre Gusmão, 1998, v. 1, p. 283-337.

FURTADO, Júnia; MONTEIRO, Nuno. Os Brasis na Histoire des deux Indies do Abade Raynal. Varia Historia, v. 32, n. 60, p. 731-777, set/dez 2016.

GERBI, Antonello. O Mundo Novo. História de uma polêmica (1750-1900). São Paulo: Companhia das Letras, 1996.

GUMBRECHT, Hans U. Depois de "Depois de aprender com a história", o que fazer com o passado agora? In: NICOLAZZI, F.; MOLLO, H. M.; ARAÚJO, V. L. de (orgs.). Aprender com a história? O passado e o futuro de uma questão. Rio de Janeiro: Ed. FGV, 2011, p. 25-42.

KOSELLECK, Reinhart. Futuro e passado. Rio de Janeiro: Contraponto/Editora da PUC-Rio, 2012.

LOCKE, John. Dois tratados sobre o governo. São Paulo: Martins Fontes, 2001.

MONTESQUIEU, Charles Secondat. De l'esprit de lois. Organização. Gonzague Truc. Paris: Garnier, 1949, v. 1.

MONTAIGNE, Michel de. Essai. Paris: Gallimard, 1950. 
MOUREAU, François. O Brasil das Luzes francesas. Estudos avançados, v. 13, n. 36, p. 165-181, 1999.

PAGDEN, Anthony. Povos e Impérios. São Paulo: Objetiva, 2002.

ROBERTSON, William. History of America. Londres: A. Strahan, 1803, v. 2.

RAYNAL, Guillaume-Thomas. Histoire phiosophique et politique des établissements et du commerce de européens dans les deux Indes. Genebra: JeanLeonard Pellet, 1781, 19 volumes.

TODOROV. A conquista da América. São Paulo: Martins Fontes, 1991.

VENTURA, Roberto. Leituras de Raynal e a Ilustração na América Latina. Estudos avançados, São Paulo, v. 2, n. 3, p. 40-51, 1988.

VENTURI, Franco. Utopia e reforma no Iluminismo. Bauru: Edusc, 2003.

VOLTAIRE. Oeuvres complètes. Organização; Louis Moland. Paris: Garnier Frères, 1879. Reimpressão: Nendeln/Liechtenstein: Kraus Reprint Limited, 1967, v. 19.

VOLTAIRE. Dictionnaire philosophique. Organização: Raymond Naves. Paris: Garnier-Flammarion, 1964.

WOLF, Hans. Raynal et sa machine de guerre: l'Histoire de deux Indes et ses perfectionnements. Stanford: Stanford University Press, 1957. 